\title{
The apolipoprotein E genotyping using the PCR-RFLP was useful to linkage analysis of Alzheimer's disease families
}

\author{
Moon Ju Oh, ${ }^{1,4}$ Eun Kee Chung, ${ }^{2}$ \\ Young Min Shin, ${ }^{3}$ Kyung Ok Lee ${ }^{1}$ and \\ Young Suk Park ${ }^{1}$ \\ 1 Department of Genetic Analysis, Seoul Clinical Laboratories (SCL), \\ Seoul Medical Science Institute, Seoul 140-230, Korea \\ 2 Department of Geriatric Psychiatry, Seoul National Mental Hospital, \\ Seoul 133-223, Korea \\ 3 Department of Psychiatry, Gang Nam Hospital Seoul 135-090, Korea \\ 4 Corresponding author: Seoul Clinical Laboratories (SCL), 7-14, \\ Dong Bing Go-Dong, Yong San-Gu, Seoul 140-230, Korea \\ Accepted 23 July 1997
}

Abbreviations: AD, Alzheimer's disease; apo E, apolipoprotein E; RFLP, restriction fragment length polymorphism

\begin{abstract}
Apolipoprotein $\mathrm{E}$ (apo E) has three common alleles (apo $\varepsilon 2, \varepsilon 3$ and $\varepsilon 4$ ) that code for three major isoforms E2, E3 and E4. The isoforms differ from each other by a single amino acid substitutions at two positions and also differ in their binding affinity for the apo $E$ receptors. Moreover, recently a strong association between the apo $\varepsilon 4$ allele and late-onset Alzheimer disease (AD) was demonstrated. In this study, were analyzed the apo $E$ genotypes using the Hhal digestion of PCR amplified samples, and the apo $\varepsilon 4$ allele frequency from 70 AD patients and 106 normal population in Korea. The results suggested that the frequency of $\varepsilon 4$ allele among the AD patients (35.7\%) was 3 times higher than that among the control population (13.7\%). The data, which are in agreement with recent reports, suggests that the apo $\varepsilon 4$ allele is associated with AD in Korea.
\end{abstract}

Keywords : Alzheimer's disease (AD), apolipoprotein E genotype, polymerase chain reaction-restriction fragment length polymorphism

\section{Introduction}

Alzheimer's disease (AD) appears to abnormal aggregation of insoluble $\beta$-amyloid peptide in senile plaques and cerebral vessels (Hilbich et al., 1991), and to degenerative disorder of central nervous system which causes serious mental deterioration, dementia and death (Flier and Underhill., 1991; Marder et al., 1994). Although the pathogenesis of amyloid deposition in AD is not completely elucidated, recent studies suggest that the apolipoprotein (apo) E4 isoform plays a key role in amyloid formation or in the pathogenesis of AD (Small et al., 1995). Apo $E$ is expressed in the liver and many peripheral tissues, where it appears to participate in redistribution of lipids. In the nervous system, apo $E$ participates in the growth and repair of injured neurons, and redistribution of cholesterol (Handlemann et al., 1992). Apo E has genetic polymorphism by three alleles, apo $\varepsilon 2$, $\varepsilon 3$ and $\varepsilon 4$, which are coding for three isoforms E2, E3 and E4 respectively (Figure 1). This polymorphism leads to the presence of six different types in the human population; three homozygotes ( $\varepsilon 2 / 2$, $\varepsilon 3 / 3$ and $\varepsilon 4 / 4)$ and three heterozygotes $(\varepsilon 2 / 3, \varepsilon 2 / 4$ and $\varepsilon 3 / 4)$ (Hansen et al., 1994; Richard et al., 1994).

Recently, many studies demonstrated an association between the apo E4 allele and late-onset AD. Thus apo E genotyping could be an important tool for identifying individual with increased risk for developing AD (Strittmatter et al., 1993; Appel et al., 1995; Corder et al., 1995a,b; Jarvik et al., 1995). In this study, we have developed the method of apo E genotyping using PCR-restriction fragment length polymorphism (PCR-RFLP) and analyzed the genotype frequencies of $70 \mathrm{AD}$ patients and 106 normal control subjects in Korea.

\section{Materials and Methods}

\section{Subjects}

The blood samples of 70 AD patients for this study were selected from Kang Nam Hospital and Seoul National Mental Hospital. Diagnosis of dementia was based on diagnostic and stastical manual of mental disorders (American Psychiatric Association 1994, 4th edition), and established by neuropsychologist. Selected mean age of $A D$ patients was 79 years, and mean age of estimated onset $A D$ was after 65 years old. The 106 control samples were selected from unrelated sex and age in the normal population from Seoul Clinical Laboratories.

\section{PCR amplification}

Genomic DNA was isolated using the method of Walsh et al. (1991), and the extracted DNA was used as the template for PCR. The PCR mixture consisted $150 \mathrm{ng}$ of genomic DNA, $2 \mu$ of $10 \times$ reaction buffer $(10 \mathrm{mM}$ Tris$\mathrm{HCl}, 50 \mathrm{mM} \mathrm{KCl}, 1.25 \mathrm{mM} \mathrm{MgCl}_{2}, 0.1 \%$ Tween), $5 \mathrm{pmol}$ of each primer 1 (5'-ATAAATATAAAATATAAATAACAGAATTC GCCCCGGCCTGGTACAC-3') and primer 2 (5'-TAAGCTTG 
GCACGGCTGTCCAAAGA-3'), $200 \mu \mathrm{M}$ of each dNTPs and 0.5 unit Taq DNA polymerase (Advanced Biotechnologies Co., Leatherland, KT, UK) in a final volume of $20 \mu \mathrm{l}$. PCR was performed for 30 cycles of denaturation at $94^{\circ} \mathrm{C}$ for $1 \mathrm{~min}$, annealing at $60^{\circ} \mathrm{C}$ for $1.5 \mathrm{~min}$ and extension at $72^{\circ} \mathrm{C}$ for $1 \mathrm{~min}$ in 9600 thermal cycler (Perkin-Elmer Co., Norwalk, CT, USA). A final extension step of $72^{\circ} \mathrm{C}$ for 5 min was also included. The PCR products were separated by $2 \%$ agarose gel electrophoresis and visualized by ethidium bromide staining.

\section{Restriction analysis of amplified DNA}

For the restricted patterns from each apo $\varepsilon$ alleles, nucleotide sequence analysis was performed using the PC/GENE computer program (Intelligenetics Inc., Mountain View, CA, USA). Five microliter of the PCR product was digested with 10 unit Hhal (New England Biolab. Co., Beverly, MA, USA) for $4 \mathrm{~h}$. The digested fragments were separated by electrophoresis on a $12 \%$ polyacrylamide gel at $100 \mathrm{~V}$ for $3 \mathrm{~h}$. After electrophoresis the gel was stained with ethidium bromide, and the polymorphic patterns were analyzed.

\section{DNA sequencing}

The apo E types analyzed by PCR-RFLP were confirmed using the direct sequencing. The PCR products were purified by DNA purification system (Wizard PCR preps, Promega, USA), and sequenced by $\mathrm{ABI} 310$ genetic analyzer (PE Applied Biosystems., Norwalk, CT, USA) following the manufacture's instruction. The sequences were compared with the previously published report (Appel et al., 1995).

\section{Results}

\section{PCR amplification and restriction analysis of apo E gene}

Apo $E$ gene had three alleles which contain two polymorphic Hhal sites on codon 112 and codon 158 (Figure 1). Figure 2 showed the restricted patterns of three homozygous and three heterozygous types. The apo $\varepsilon 2$ allele was characterized by the presence of the 104 and $91 \mathrm{bp}$ bands, apo $\varepsilon 3$ by the 91,53 and 48 bp bands, and apo $\varepsilon 4$ by the 72,53 and 48 bp bands. Each of the heterozygous types was showed by mixed bands of homozygotes. As shown in Figure 3 the partial nucleotide sequences of the apo $\varepsilon 3 / 3$ and apo $\varepsilon 3 / 4$, were most frequently found alleles in normal and AD patients. They were confimed by direct sequencing, and the heterozygote generated two peaks at the same base position.

\section{The apo E genotype frequencies for $A D$ patients and control group}

The apo E genotype frequencies for AD patients and control subjects were compared. As shown in Table 1, allelic frequences of AD patients were $44.3 \%$ for $\varepsilon 3 / 4$, $25.7 \%$ for $\varepsilon 3 / 3,12.9 \%$ for $\varepsilon 2 / 3,10.0 \%$ for $\varepsilon 4 / 4,7.0 \%$ for $\varepsilon 2 / 4$ and $0 \%$ for $\varepsilon 2 / 2$. The apo $E$ allele frequencies were 0.100 for $\varepsilon 2,0.543$ for $\varepsilon 3$ and 0.357 for $\varepsilon 4$. The apo $E$ genotype frequencies for control subjects were $59.4 \%$ for $\varepsilon 3 / 3,19.8 \%$ for $\varepsilon 3 / 4,13.2 \%$ for $\varepsilon 2 / 3,3.8 \%$ for $\varepsilon 2 / 4$ and $1.9 \%$ for $\varepsilon 2 / 2$ and $\varepsilon 4 / 4$, and allele frequencies were 0.763 for $\varepsilon 3,0.137$ for $\varepsilon 4$ and 0.100 for $\varepsilon 2$. A comparison of the frequencies for apoE genotypes among the $A D$ and control subjects demonstrated a significant difference between the two groups $(P=0.0001)$. Apo $\varepsilon 3 / 4$ was the most common genotype in the AD patients (44.3\%),

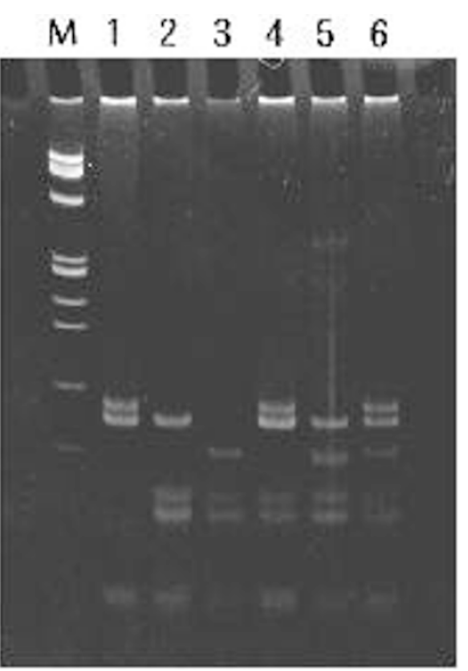

Figure 2. Six RFLP types of apo $E$ gene digested by Hhal. After amplification of apoE genomic DNA by PCR, the amplified products were completely digested by Hhal and analyzed on the $12 \%$ polyacrylamide gels. M, PhiX174/Haelll molecular weight marker; lane 1, apo $\varepsilon 2 / 2$; lane 2, apo $\varepsilon 3 / 3$; lane 3, apo $\varepsilon 4 / 4$; lane 4, apo $\varepsilon 2 / 3$; lane 5 , apo $\varepsilon 3 / 4$ and lane 6 , apo $\varepsilon 2 / 4$.

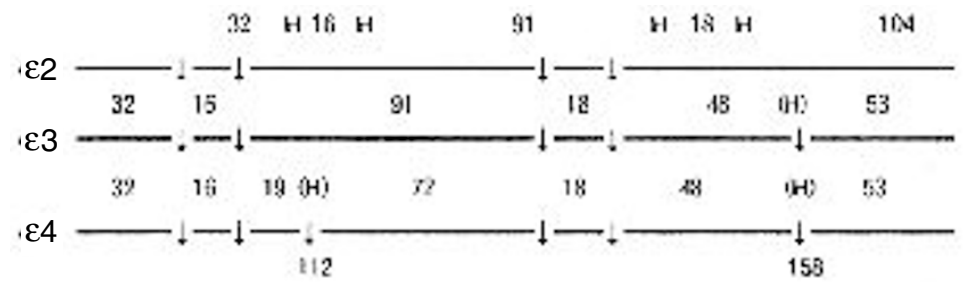

Figure 1. Restriction map of three principal alleles, $\varepsilon 2$, $\varepsilon 3$ and $\varepsilon 4$ of apo $\mathrm{E}$ gene. The map was drawn based on the published sequence. The polymorphic regions are codon 112 and $158 . \mathrm{H}$ and $(\mathrm{H})$ mean cutting sites and variant sites of $H$ hal, respectively. Numbers between cutting sites indicate fragment size in base pairs. 
Table 1. The frequencies of apoE alleles and genotypes in $A D$ patients and control subjects

\begin{tabular}{|c|c|c|c|c|c|c|c|c|c|}
\hline & \multicolumn{3}{|c|}{$\begin{array}{c}\text { apo } \varepsilon \text { allele frequencies } \\
\%\end{array}$} & \multicolumn{6}{|c|}{$\begin{array}{c}\text { apo } \varepsilon \text { genotypes } \\
\%(n)\end{array}$} \\
\hline & $\varepsilon 2$ & $\varepsilon 3$ & $\varepsilon 4$ & $\varepsilon 2 / 2$ & $\varepsilon 2 / 3$ & $\varepsilon 2 / 4$ & $\varepsilon 3 / 3$ & $\varepsilon 3 / 4$ & $\varepsilon 4 / 4$ \\
\hline $\begin{array}{l}\text { AD patients } \\
(\mathrm{n}=70)\end{array}$ & 10.0 & 54.3 & 35.7 & $0.0(0)$ & $12.9(9)$ & $7.0(5)$ & 25.7 (18) & $44.3(31)$ & $10.0(7)$ \\
\hline $\begin{array}{l}\text { Control subjects } \\
\qquad(n=106)\end{array}$ & 10.0 & 76.3 & 13.7 & $1.9(2)$ & $13.2(14)$ & $3.8(4)$ & $59.4(63)$ & $19.8(21)$ & $1.9(2)$ \\
\hline
\end{tabular}

whereas apo $\varepsilon 3 / 3$ was in the control subjects (59.4\%). The $\varepsilon 4$ allele frequencies were also significantly different between AD patients (0.357) and control subjects $(0.137)$ $(P<0.0001)$ (Table 1).

\section{Discussions}

The association of the apo $\varepsilon 4$ allele has recently been reported for both late-onset familial AD (Saunder et al., 1993; Kosumen et al., 1995) and sporadic AD (Strittmatter et al., 1993; Corder et al., 1994; Tsai et al., 1994).

Initially, apo E polymorphism was determined through phenotyping by means of isoelectric focusing technique which allowed the detection of charge variations consequent upon the minor sequence difference between the principal isoform (Utermann et al., 1977). But the isoelectric focusing technique requires a large volume of sample, time-consuming and expensive. To avoid these problems, apo E genotyping based on PCR has been developed and several different approaches have been proposed; use of allele-specific oligonucleotide (ASO) (Weisgraber et al., 1988), amplification refractory mutation system (ARMS) (Wehhon et al., 1991), single strand confomation polymorphism (SSCP)-sequencing (Aozaki et al., 1994) and RFLP (James et al., 1990). The SSCPsequencing technique is most accurate and can detect rare mutations, but tends to time-consuming and inappropriate for routine test. In contrast RFLP is a simple, accurate and rapid method, and useful to analyze the allelic variation of apo $\mathrm{E}$ (James et al., 1990).

In the present study, we investigated the apo $\varepsilon$ allele frequency of $A D$ patients and normal subjects by PCRRFLP. Approximately $35.7 \%$ of the AD patients had at least one apo $\varepsilon 4$, and apo $\varepsilon 4 / 4$ allele may account for $10.0 \%$ of the $A D$ case. Our result was similiar to previously published reports, which showed a significantly higher apo $\varepsilon 4$ allele frequency in the AD group compared to control group (Michael et al., 1994; Tsai et al.,1994; Kosunen et al.,1995). The apo $\varepsilon$ allele frequency was also dependent on the ethnic and genetic background of the population being examined, therefore control group determination is also very crucial. The apo $\varepsilon$ allele frequencies of control

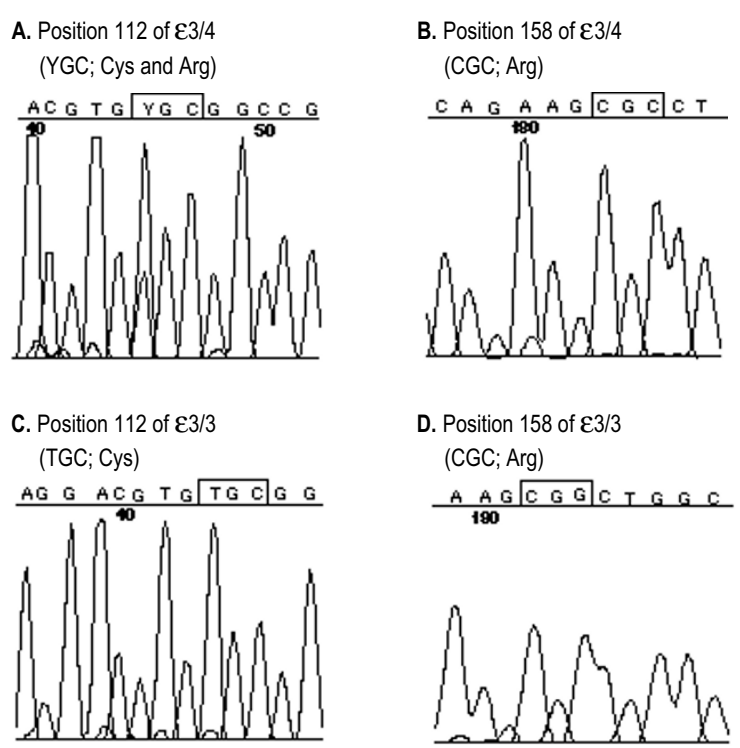

Figure 3. DNA sequence analysis at position 112 and 158 of $\varepsilon 3 / 4$ ( $A$ and $B$ ) and apo $\varepsilon 3 / 3$ (C and D). Apo $\varepsilon 3 / 4$ showed both of arginine (CGC) and cysteine (TGC) at position 112 by two peaks, and same arginine (CGC) at position 158. Apo $\varepsilon 3 / 3$ showed cysteine (TGC) at position 112 and arginine (CGC) at position 158. Amplified products were purified and sequenced using $A B I 310$ genetic analyzer. All DNA sequences were confirmed by reading antisense strands.

subject in Korean population were also similiar to previously published Japanese data (Tsukamoto et al., 1993).

Apo $\varepsilon 4$ might be an important factor for the detection of development of AD. Moreover apo $\varepsilon 4$ gene could be considered as susceptibility gene of AD. All persons who had apo $\varepsilon 4$ gene were not patients and some people may get the disease without having the apo $\varepsilon 4$, therefore it is not absolute factor to diagnose the AD (Boyles et al., 1995; Corder et al., 1995).

In conclusion, we suggested that the apo $\varepsilon$ genotyping using the PCR-RFLP was useful for linkage analysis of $A D$ families. Further studies are necessary for broad range of $A D$ group, accurate differentiation according to sex and age, precise onset age and family history. 


\section{Acknowledgements}

This work was supported by grants from the Seoul Medical Science Institute of Korea (97-S1001). We thank Dr. J. S. Han (Department of Biochemistry, College of Medicine, Hanyang University) for critical review of this manuscript.

\section{References}

Aojaki, R., Kawaguchi, R., Osaga, U., Hikiji, K., Kubo, N. and Sokurabayasi, I. (1994) Rapid identification of the common apo $E$ isoform genotype using polymerase chain reactionsingle strand conformation polymorphism (PCR-SSCP). Mol. Cell. Probes 8: 51-54

Appel, E., Eisenberg, S. and Roitelmen, J. (1995) Improved PCR ampli-fication/Hhal restriction for unambiguous determination of apolipoprotein E allele. Clin. Chem. 45: 187-190

Boyles, J. K., Pitas, R. E., Wilson, E., Mahley, R. W. and Taylor, J. M. (1985) Apolipoprotein $\mathrm{E}$ associated with astrocytic glia of the central nervous system and with nonmyelinatng glia of the peripheral nervous system. J. Clin. Invest. 76: 1501-12

Corder, E. H., Saunders, A. M., Strittmatter, W. J., Schmechel, D. E., Gaskellm, P. C. Rimmler, J. B., Haines, J. L. and Pericak-vance, M. A. (1994) Protective effect of apolipoprotein E type 2 allele for late onset Alzheimer's disease. Nat. Genet. 7: 180-183

Corder, E. H., Saunders, A. M., Strittmatter, W. J., Schmechel, D. E., Gaskell, P. C., Locke, P. A., Conneally, P. M., Schmader, K. E. and Tanzi, R. H. (1995a) Apolipoprotein E survival in Alzheimer's disease patients, and the competing risks of death and Alzheimer's disease. Neurology 45: 1323-1328

Corder, E. H., Saunders, A. M., Schmechel, D. E., Pericak-Vance, M. A. and Roses, A D. (1995b) There is a pathologic relationship between Apo E-epsilon 4 and Alzheimer's disease. Arch. Neurol. 52: 650-651

Flier, J. S. and Underhill, L. H. (1991) $\beta$-Amyloid and the pathogenesis of Alzheimer's disease. N.Engl. J. Med. 325: 1849-1857

Handlemann, G. E., Boyles, J. K., Weigraber, K. H., Mahley, R. W. and Pitas, R. E. (1992) Effects of apolipoprotein $E, \quad \beta$-very low density lipo-protein, and choresterol on the extention of neurites by rabbit dorsal ganglion neurons in vitro. J. Lipid. Res. 33: 1677-1680

Hansen, P. S., Gerdes, L. U., Klausen, L. C., Gregerson, N. M. and Faerfgeman, O. (1994) Genotyping compared with protein phenotyping of the common apolipoprotein $E$ polymorphism. Clin. Chem. 31; 224(2): 131-137

Hilbich, C., Kisters-Woike, B., Read, J., Masters, C. L. and Beyreuther, K. (1991) Aggregation and secondary structure of synthetic amyloid $\beta A 4$ peptides of Alzheimer's disease. J.Mol. Biol 218: 149-163

James, E., Hixson, J. E. and Vernier, D. T. (1990) Restriction isotyping of human apolipoprotein $\mathrm{E}$ by gene amplification and clevage with Hhal. J. Lipid Res. 31: 545-548

Jarvik, G. P., Wijsman, E. M., Kurkull, W. A., Schellenberg, G. D., Yu, C. and Larson, E. B. (1995) Interaction of apolipoprotein E genotype, total cholesterol level, age, and sex in prediction of alzheimer's disease: a case-control study. Neurology 45: 1092-1096

Kosunen, O., Talasniemi, S., Lehtovirta, M., Heinonen, O., Helisalmi, S., Mannermaa A., Paljarvi, L.,Ryynanen, M., Riekkinen, P. J. and Soininen, H. (1995) Relation of coronary atherosclerosis and apolipoprotein $\mathrm{E}$ genotypes in alzheimer patients. Stroke 26: $743-748$
Marder, K., Maestre, G., Cote, L., Mejja, H., Alfaro, B., Halim, A., Tang, M., Tycko, B. and Maywux, R. (1994) The apolipoprotein E4 allele in Parkin's disease with and without dementia. Neurology 44: 1330-1331

Michael, L., Peacock, B. S. and John, K. F. (1994) Apo E allelic associ-ation with Alzheimer's disease: independent confirmation using denaturing gradient gel electrophoresis. Neurology 44: 339-341

Richard, P., Thomas, G., De Zulueta, M. P., De Gennes, J. L., Thomas, M., Cassigne, A., Bereziat, G. and Iron, A. (1994)Common and rare genotypes of human apolipoprotein $E$ determined by specific restriction profiles of polymerase chain reactionamplified DNA. Clin.Chem. 40: 24-29

Saunders, A. M., Strittmatter, W. J., Schmechel, D., Pericak-Vance, M. A. and Joo, S. H. (1993) Association of apolipoprotein E allele $\varepsilon 4$ with late-onset familial and sporadic Alzheimer's disease. Neurology 43: 1467-1472

Small, G. W., Mazziota, J. C., Collins, M. T., Bsxter, L. R., Phelps, M. E., Msandelkern, M. A., Schneider, J. A., Gearing, M., Robbins, R. S. and Mirra, S. S. (1995) Apolipoprotein $\mathrm{E}$ type 4 allele and cerebral glucose metabolism in relatives at risk for familial Alzheimer's disease. Ann. Neurol. 38: 131-135

Strittmatter, W. J., Saunders, A. M. and Schmechel, D. (1993) Apolipo-protein E: highavidity binding to $\beta$ amyloid and increased frequency of type 4 allele in late-onset familial Alzheimer's disease. Proc. Natl. Acad. Sci. USA 90: 1977-1981

Tsai, M. S., Tangalos, E. G., Peterson, R. C., Smith G. E., Schaid, D. J., Kokmen, R. J. and Thibodeau, S. N. (1994) Apolipoprotein E: risk factor for alzheimer disease. Am. J. Hum. Genet. 54: 643-649

Tsukamoto, K., Watanabe, T., Matsushima, T., Kinoshita, M., Kato, H., Hashimoto, Y., Kurokawa, K. and Teramoto, T. (1993) Determination by PCR-RFLP of apoE genotype in a Japanese population. J. Lab. Clin. Med. 121: 598-602

Utermann, G., Hees, M. and Steinmetz, A. (1977) Polymorphism of apoli-poprotein E and occurrence of dysbetalipoproteinaemia in man. Nature 269: 604-607

Walsh, P. S., Metzer, D. A. and Higuchi, R. (1991) "Chelex 100 as a medium for simple extraction of DNA for PCR-based typing from forensic materials. Biotechniques 10: 506513

Weigraber, K. H., Newhouse, Y. M. and Mahley, R. W. (1988) Apolipo-protein E genotyping using the polymerase chain reaction and allele specific oligonucleotide probes. Biochem. Biophys. Res.Commun. 157: 1212-1217

Wenham, P. R., Newton, C. R. and Price, W. H. (1991) Analysis of apoli-poprotein E genotypes by the Amplification Refractory Mutation System. Clin. Chem. 37: 241-244 